\title{
Nationalism Based on Western Education in the Characters in "Child of All Nations"
}

\author{
Hamid Farahmadnian \\ Faculty of Modern Languages and Communication, Universiti Putra Malaysia \\ FarahmandianH@gmail.com \\ Dr. Sokol Pacukaj \\ Aleksander Moisiu University of Durres \\ sokolpacukaj@gmail.com
}

\section{Doi:10.5901/mjss.2014.v5n20p2676}

\section{Abstract}

Association between Western education and the brewing spirit of nationalism is well documented in many of the characters in Child of All Nations, most notably Minke, Kommer, and Jean Marais. It would not be too farfetched to claim that without Western education, Minke and his comrades would not have been able to discard the sense of respect and admiration that they hold for their colonisers - a consequence of extended exposure to the Dutch's self-propaganda of their eminence. Indeed, the fight for Indonesia's independence would have been a slow and sluggish, perhaps even a failed one. However, before delving into how Western education was able to sow the seed of nationalism in the characters in the book, it is only prudent to first examine the education system that was offered in Indonesia during the Dutch colonialism era.

Keywords: Western Education, Nationalism, Colonialism, Indonesian Literature

\section{Introduction}

The link between the spirit of nationalism and education has long been established since the 18th century, with Jean Jacques Rousseau (1712-1778) being one of the main advocators of the association between the two elements. Intrigued by the idea of the spirit of nationalism, its development in a country or society, and citizenship, he proposed that patriotism is a sentiment that can not only be moulded, but also generated in a person. Rousseau considered this a part of the many tasks a capable government should perform, citing that "The task of governments was to carve the mould...in which the children of nations should be shaped" (235); and this, he argued, can be achieved through proper means: the education institutions. Instead of focusing on the development of the people's intellect, education should be used to develop their character, and thus, their sense of nationalism.

Since then, Rousseau's suggestion has been most influential in both the designing of education syllabus, both within and without Europe, as well as the philosophies of other intellectuals. Johann Gottfried Herder (1744-1803) is one such scholar who subscribes to Rousseau's opinion that education should merely be a character-building instrument. The extent of their similarities, however, ends there. While both Rousseau and Herder are in agreement of the primary role of education, they subscribe to completely different notions of nationalism.

Rousseau's notion of nationalism was that of political nationalism (Barnard 1998; qtd. in Wiborg 236), a type of nationalism that is heavily rooted in the idea of the nation-state as the determinant of one's national identity. Political nationalism is largely dependent on the geographical borders of a country to establish a person's national identity, and by extension, his or her patriotism. It differentiates the two sides of a man: man as a being, and man as a citizen, and further extends the idea of 'man as a citizen' by introducing the concept of general will. Wiborg (2000) describes this concept as "a binding force within a sovereign political entity which formed the basis for the distinction between different states and the creation of distinguishable groupings of people" (236); it 'binds' the people according to their states through the means of common want and desire shared between the citizens (no longer man). Education, then, will bear the responsibility of 'guiding' this will so that it can be directed towards building the nationalistic spirit of the people.

Herder's brand of nationalism, on the other hand, is inclined towards the other end of the spectrum, aptly named cultural nationalism (Barnard 1998; qtd. in Wiborg 236). Unlike Rousseau's geographically-dependent nationalistic spirit, this category of nationalism is, instead, reliant on the idea of cultural and spiritual development of the people. Cultural nationalism posits that a nation's national identity is derived from a natural social framework which is entirely organic (i.e. 
without concrete borders, organisations, governments or rulers), and employs the idea of 'bonds' to link the people together as a 'nation', such as traditions and expectations among the people. More than that, however, Herder's cultural nationalism places a lot of emphasis on the role of language and mother tongue as a significant feature that contributes to the development of nationalism. It believes that "political rested on the possession of common culture rooted in language" (240), claiming that this is the cultural nationalism is the structure that could promise and ensure the existence of liberty, freedom, and equality. Due to this difference between their idea of nationalism, Herder finds it necessary to modify Rousseau's description of education, specifying that there are two purposes to education:

1) To produce leaders who can guide the people towards the emergence of a culturally nationalistic 'nation'

2) To transmit the cultural heritage of one generation to the next generation (Wiborg 240)

It is undeniable that both Rousseau's and Herder's ideas of education and nationalism are inspiring and accomplished, but when pitted against the setting of a colonised country, it is rendered useless. The education system devised to create nationalistic sentiments is functional only when it is applied to the nation's own people because, as Rousseau puts it, a nation is motivated by its general will. A colonised country, in contrast, is neither part of the nation nor the general will, and thus, is not influenced the way the original nation would.

That is not to say, however, that the colonised country is not affected at all by what little amount of education the colonisers had provided during their reign over the country. There is little doubt that there will be an effect from the education provided to the natives (usually reluctantly), but the outcome is, more often than not, a reversal of Rousseau's and Herder's expectations of education in creating a nationalistic spirit to the government providing the scholarship. Instead of causing the natives to swear loyalty to the colonisers (i.e. provider of education), the learning system provided to the colonised people induced in them a loyalty to their own land, thus leading to the effort to free themselves from the colonisers' sovereignty.

Such is the premise that Pramoedya Ananta Toer's Child of All Nations is built on. In this second book of Pramoedya's Buru tetralogy, Indonesia is still under the brutal rule of the Dutch, but with the provision of Western education to certain groups of the natives, there begins a desire to free Indonesia from the clutches of their colonial masters. This association between Western education and the brewing spirit of nationalism is well documented in many of the characters in Child of All Nations, most notably Minke, Kommer, and Jean Marais. It would not be too farfetched to claim that without Western education, Minke and his comrades would not have been able to discard the sense of respect and admiration that they hold for their colonisers - a consequence of extended exposure to the Dutch's self-propaganda of their eminence. Indeed, the fight for Indonesia's independence would have been a slow and sluggish, perhaps even a failed one.

However, before delving into how Western education was able to sow the seed of nationalism in the characters in the book, it is only prudent to first examine the education system that was offered in Indonesia during the Dutch colonialism era.

On a general scope, the educational development in Indonesia can be divided into three (3) stages: 1) the autochthonous organisation; 2) the colonial era; and 3) the modern education (Justus M. van der Kroef, 147-8).

The first stage of the educational development in Indonesia, i.e. the autochthonous organisation, is, simply put, the education offered prior to any interference from any colonial powers. At this stage, children were mainly 'educated' through two primary traditional methods: observation and imitation. Children were encouraged to learn from their parents by observing and imitating them while they were at work, often picking up necessary and practical skills through a process of trial and error. At the same time, however, there exists also Islamic schools that are an important part of Indonesia's pre-colonial education system.

The second stage includes all the education systems offered by the few colonisers who had once colonised Indonesia, and this consists of the Portuguese (early 16th century), the Verenigde Ooostindische Compagnie (VOC, 1602-1800), the British empire (temporarily from 1814-1815), and lastly the Dutch government (1815-1920).

The final stage of the educational development began after Indonesia obtained their independence, starting with the rule of their first government, Orde Lama, and after that, its successor, Orde Baru.

This paper's and Pramoedya's Child of All Nations' concern lies primarily with the second stage of educational development in Indonesia - that of the colonial era - with a focus on the education offered by both the VOC and the Dutch government. Having reviewed the schooling system during this era, Van der Kroef (1957) generalises that there are three distinguishing characters to the system.

Firstly, the education system provided by the Dutch is an imitation of the education system in Netherlands. It duplicates the type of schooling and the standards of the system in Holland at that time.

Secondly, the colonisers made sure to keep the number of schools available to the natives low. Understandably, this caused the number of local graduates as well. Van der Kroef claims that underlying motive for such a move was to 
make certain that both the colonial system and the traditional structure supporting it would not be disrupted.

Lastly, the Dutch employed a stance in their offered education that is almost reminiscent of the British's divide-andrule system, employing an element of racial distinction to keep separated the Western school system from the village school system. As with all colonialist education, the Western school system is deemed the superior system, with Dutch as the language of instruction, and consisting of primary, secondary, and higher institutions of learning. The village school system, on the other hand, uses the Indonesian vernacular as their medium of instruction, comprising only schools of the first three primary grades.

Van der Kroef was both accurate and honest in saying that "these features of the colonial educational system adversely affected the developing Indonesian community" (Van der Kroef 148). This applies to the schooling system during the rule of both the $\mathrm{VOC}$ and the Dutch government, regardless of the different approaches that they employed in providing education.

During the rule of the VOC, education was mostly limited to the eastern part of Indonesia, as well as Batavia (now known as Jakarta) as these two regions are the more developed areas of the country (Batavia was the centre of VOC's administration). The main purpose of for the provision of education during the VOC's rule is to create workers capable enough to "support Dutch business interests and Protestant missionaries" (Wangsalegawa 38). At the same time, they also aimed to use education to help eradicate the Catholic faith in Indonesia, substituting it with Protestantism instead. Due to this religious undertone, much of the education provided during VOC's time was given to both Dutch and native children, without bias, through the church institutions and missionaries.

It is also necessary to note that aside from the Western education provided by the VOC, there were other preexisting forms of education at that time, too, such as the elementary schools, Latin schools, Seminarium, Theologicum (seminaries), Academie der Marine (marine academies), Chinese schools, and Islamic schools. These education institutions were not bothered by the VOC, and were allowed to operate without interference.

When the Dutch government took over after the temporary rule by the British, the VOC education system that was heavily based on religion was scraped off. Instead, the new education system was rooted in the concept of aufklarung (enlightenment), in which it is believed that education can help improve the society and its economy. The Dutch government's purpose in providing education is also more practical; they only wish to produce more people to fill the workforce gap for the colonisers, particularly government employees and plantation labourers (Wangsalegawa 43).

The types of school that were established during this time were chaotically numerous, with the primary education institutions of the time being Sekolah Kelas Satu, Sekolah Kelas Dua, Sekolah Desa, Europese Lagere School (ELS), Hollands Chinese School (HCS), Hollands Inlandse School (HIS), Meer Uitgebreid Lager Onderwijs (MULO), Hogere Burger School (HBS), and the Algemene Middlebare School (AMS). Of all the schools above, the first four schools are the institutions that acted as the 'foundation' of the Dutch education system, whereas the remaining five are the tertiary or 'extended' components that are based on the first four schools.

It is through these institutions that Minke and some of his comrades were educated in the ways of the West, thus exposing them to not only the language, but also the ideologies and philosophies that played a part in advancing the Indonesians in their bid for independence. Minke himself is a HBS graduate (251), a prestigious institution that followed the same curriculum as university preparatory schools in Netherlands. Students, especially natives, who graduated from the HBS are regarded with much admiration and respect. Minke, of course, has double the dose of respect as he is not only just an HBS graduate with a wide repertoire of language (he can speak Dutch; French; English; Javanese, both high and low; as well as a smattering of German) and a writer, but also an aristocrat.

There is also the high possibility that Kommer may be a student from the MULO despite the fact that it is not explicitly revealed in the novel. This is deduced from the display of intelligence that Kommer, a mixed blood and a nonaristocrat, shows in his speech and persuasion of Minke to write in Javanese, as well as his detailed knowledge of the events that occur outside of Indonesia. MULO is actually a post-ELS education, and it is the first type of such education that does not conform to the schooling system from Netherlands. It is an alternative for native students who attempted and failed to enter the HBS, but still wished to further pursue their studies at a tertiary level. This academic institution is most responsible for the existence of non-aristocratic natives who possess advanced education, also known as the elite intellectuals.

A host of other characters, too, learnt and benefited from Western education. Panji Darman, the adopted son of the preacher, Dapperste, is the governor-general of the Netherland Indies (Indonesia), and he most possibly received his Western education from a Western religious institution. Nyai Ontosoroh, Minke's strong-hearted and dynamic mother-inlaw, too, has received some amount of Western education from Mr Melemma, her 'husband', so as to allow her proper management of the sugar production factory.

Another character who benefited from Western education is Raden Adjeng Kartini, a character that is never directly 
referred to in the book, but mentioned quite often. We can assume that Pramoedya's Kartini is a reflection of the actual Raden Adjeng Kartini, a figure who is renowned as an Indonesian national heroine and a local feminist. Her father, a bupati, was open-minded and willing to give his daughter a Dutch education even though education opportunities were limited for girls throughout the history of education in Indonesia. This move has exposed Kartini to many Western reading materials and advanced Western philosophies such as feminism, which then fuelled her "concern for the plight of Indonesians under conditions of colonial rule and for the restricted roles open to Indonesian women" (Kartini, Raden Adjeng; Encyclopaedia Britannica Library).

Khouw Ah Soe, too, has received Western education prior to his coming to Indonesia: “...I'm a graduate of the English-language secondary school at Shanghai" (67); and it is also doubtless that both Jean Marais, a French painter, is Western-educated. Jean Marais' emphasis on the importance of one's own mother tongue is reflective of Herder's cultural nationalism, indicating that he had been exposed to Herder's thoughts at one point of his life, a thinker who can only be accessed through Western education when living in Indonesia.

Lastly, there is Ter Haar, a mysterious journalist figure whom Minke meets aboard a ship on his way to Betawi. Ter Haar's character is an odd one, perhaps almost eccentric. He claims that he is uneducated: "Sorry, Mr. Minke, I've never been to school. And anyway, what would be the point of teaching things like that?" (258), and yet his knowledge of the world far surpasses those shown by the other characters in Child of All Nations. It appears that much of his 'education' comes from discussions within a group called the Radical Group (269). Through Ter Haar, Pramoedya reminds his readers that education does not only come in a structuralised, systematic form, or what we know as formal education. Rather, education can be obtained in other forms as well, such as group discussions, newspapers, and even street talks, i.e. informal education. Ter Haar is proof that this concept applies to even 'supreme' educations systems such as the Western education too.

The benefits and impact of Western education on the nationalistic spirit of the characters in the book are colossal, but perhaps the biggest effect lies in the acquisition of Western languages. By acquiring these languages (particularly English, Dutch and French), a whole world of new knowledge and beneficial ideologies is opened to the learner. Not only are they free to explore and read from books, they are also able to speak to foreigners to learn of new things.

Without knowledge of Western languages, Minke would not have been able to correspond with the de la Croix family (a family of three: Miriam and Sarah, and their father, Herbert) who are constantly urging him towards developing a nationalistic spirit. In her letters to Minke, Miriam de la Croix tries very hard to persuade him to relinquish his blind trust and pride towards the Dutch government: "I write this with a heavy heart... The north [the colonisers' country] contains no magic. But it is true that you must keep your eyes to the north always in vigilance" (55). She urges him to strike a balance between taking pride in his cultural heritage and revolutionising "the warped attitude of the people of Java and the Indies towards the world" (103) with the necessary Western knowledge to give birth to a new race of more advanced and knowledgeable natives (100-4).

As mentioned earlier, language, too, allowed Minke and his comrades access to books that contain much of the valuable teachings, ideologies, and latest news. Without Western knowledge, they would not have been introduced to the French Revolution and the beliefs that served as the driving force of the Revolution.

The French Revolution took place amidst a state of affairs that was almost akin to the condition of Indonesia during the reign of the Dutch government although France was not under colonisation. The increasingly affluent commoners of the country (also known as the bourgeoisie) were unhappy with their exclusion from the political arena of their country. At the same time, the lower class in the social hierarchy of France, the peasants, was beginning to rebel against the restrictive feudal system that were oppressive. Their resentment was further fuelled by the near-bankruptcy of the country due to their participation in the American Revolution, as well as country-wide failure of crops amidst the economic difficulties.

Such a situation would strike a chord within Minke and his people considering the similarities that their situations bear to each other. The poor and non-aristocratic natives, too, were forced to undergo what the peasants in France had to; they were forced to toil the ground for the sake of the colonisers (Indonesia) / aristocrats (France). Not only that, neither parties were allowed to partake in the political scene of their own country. Indonesia, too, was being taken advantage of by their colonisers agricultural-wise as the Dutch ploughed the lands of Indonesia for wealth through the Culture System, leaving the land barren and dry.

As such, just as how the French managed to rouse their spirit of nationalism through the effort of the philosophes of their country who campaigned strongly for social and political reforms, it is the duty of Minke and the writers of his nation to learn from the West and to revolutionise their people through what they have learnt. This, in turn, would help to promote nationalism in them. The French Revolution, too, could serve as the end goal that the people of Indonesia should strive to achieve. If the French commoners were capable of breaking away from their oppressors, then so could 
the Indonesians. Throughout the novel, it is towards this idealistic state of liberty, equality, fraternity (the underlying ideologies behind French Revolution) that Minke is striving towards, and he does achieve it to a certain degree: "...You are truly a child of the French Revolution" (179).

Aside from the French Revolution, Western education - more specifically, Western languages - also exposed to Minke the conquests of Japan and the many different reactions towards the movement. In the late 19th and early 20th century, the Japanese had started an effort to expand their influence, encroaching into China. This endeavour forced Western powers to acknowledge the Japanese as an equal: "The conferring of equal status on the Japanese in these Dutch-conquered islands startled all who heard it" (49).

Minke's knowledge of Japan's conquests and the reactions to it comes from reading materials, mostly Western: "...I returned to my old activities: reading the papers and certain magazines, books, and letters; writing notes and articles..." (47). Through his collected materials, Minke is not only able to learn about the blow-by-blow development of Japan's advancement, but is also able to construct a more 'objective' view of the situation in spite of sarcastic comments by several parties (47-53).

In this sense, Western education has made it possible and encouraged Minke to practise critical thinking, a trait often associated with the West, in his views of the world. This way, he finds himself building a strong sense of admiration and awe at the ability of an Eastern country that appears to be as great as that of a Western country. Thus, like the French Revolution, Japan's success becomes a motivation for Minke's growing nationalistic spirit; Japan has shown that Eastern countries are not inferior to Western powers, and thus, inferiority is not an excuse for the East to submit to the West.

These are some of the incidents that drastically influenced Kommer, Jean Marais, and later, Minke, in their understanding of the system in Indonesia. Without these Western thoughts on equality, freedom, and independence, Kommer and Jean Marais would not have tried to persuade Minke to write in his own vernacular language to the extent of provoking him. Accordingly, Minke would not have thought to try to approach Trunodongso and his family during his visit to Tulangan with his mother-in-law, nor would he strive to understand the injustice that Surati and her family had to go through. He learns to see his people in a gentler light instead of the harsh lens of the colonisers, and that is what prompted him to begin writing for his people's sake, to his people.

Later, when Minke meets Ter Haar, the European journalist who was a former subeditor at the Soerabaiaasch Nieuws, on his way to Betawi to further his studies, Minke will come to discover the limited view and knowledge that he has of the world despite his so-called prestigious BHS education. From the very beginning of their meeting, Ter Haar talks to Minke of the many uprisings and political movements that were happening around the world, introducing him to the lifestyle of a liberalist. Minke realises that he knows little about world-changing events such as the Spanish-American War which then led to the uprisings in the Philippines and the murder of the respected Jose Rizal $(265-6,276)$; the election of Philippines' first president, Emilio Aguinaldo (275); as well as the revolution of the Mexicans natives against their Spanish colonisers (266).

In fact, it was also Ter Haar, an outsider, who had to open Minke's eyes to the injustice that was being done by Dutch colonisers to his own people in their own land because the news were not printed in the local papers. Ter Haar exposes Minke to the scandal of the royal family in Holland who were accused of having "taken from the peasants of Java the amount of 951 million guilders" (255); the truth of Soerabaiaasch Nieuws as a sugar paper (252-3); as well as the attempt by the Governer-General of the Netherlands Indies to please the crown prince of the Russian czar when he came to Batavia by offering him hunting trips and a bupati's daughter for entertainment, merely because Russia was unhappy with the decision to grant the Japanese equal status with the Europeans (256-7).

It is Ter Haar's goal to direct Minke away from the Western idealisms by showing him the wickedness of the West, but to the end, Minke comes to realisation that it is only through Western education that he will be able to fight the colonisers: "...No, Ter Haar the Coaxer, I still need Europe as a teacher, including you yourself. Only through your own strength can we confront you, Europe" (276).

Aside from the motivating news of upheavals mentioned above, Western education also brought in revolutionary writings, one of them being those of the famed Multatuli. Multatuli is the pseudonym of Eduard Douwes Dekker, said to be one of Netherlands' greatest writers who strove to expose the Dutch exploitations of the Javanese natives. His book, Max Havelaar (1860), was touted to be one of his best written tomes, and it is the title of this book that Minke takes on as his penname in the Buru tetralogy's first book, The Earth of All Mankind. Anyone who claims to fight for Indonesia would have read Multatuli's book, and it later became one of the motivating factors for the natives to fight for their independence. Thus, this Western tome becomes the earliest eye-opener to the Dutch's wickedness, and also the yardstick for Minke, Kommer, and their other comrades in their bid to free Indonesia.

In short, even though it was the West who colonised the natives, it was also the West who provided the natives 
with means to fight for their independence. Indeed, without the materials provided by the Western education, Minke, as the protagonist of the book, would have continued to worship the Dutch colonialists without knowing the reality of the situation. The nationalistic spirit, too, would have been less successfully roused within the characters in Child of All Nations.

\section{References}

"French Revolution." Encyclopaedia Britannica. Encyclopædia Britannica 2006 Ultimate Reference Suite DVD. Electronic. Retrieved 27 April 2012.

Hans, Nicholas. "Nationalism and Education in Asia." Comparative Education Review 2.2 (1958): pp. 4-12. Print.

"Kartini, Raden Adjeng." Encyclopaedia Britannica. Encyclopædia Britannica 2006 Ultimate Reference Suite DVD. Electronic. Retrieved 27 April 2012.

Kroef, Justus M. van der. "Education in Indonesia." The Phi Delta Kappan 39.3, Problems and Promises of Education in Asia (1957): pp. 147-151. Print.

"Multatuli." Encyclopaedia Britannica. Encyclopædia Britannica 2006 Ultimate Reference Suite DVD. Electronic. Retrieved 27 April 2012.

"Sino-Japanese War." Encyclopaedia Britannica. Encyclopædia Britannica 2006 Ultimate Reference Suite DVD. Electronic. Retrieved 27 April 2012.

Toer, Pramoedya Ananta. Child of All Nations. New York: William Morrow and Company, Inc. 1979. Print.

Wangsalegawa, T. "Origins of Indonesian curriculum theory and practice: Possibilities for the future." Ph.D. dissertation, University of Illinois at Chicago, United States -- Illinois. Dissertations \& Theses: Full Text. (Publication No. AAT 3381139). Retrieved 16 April 2012.

Wiborg, Susanne. "Political and Cultural Nationalism in Education. the Ideas of Rousseau and Herder Concerning National Education." Comparative Education 36.2, Special Number (22): Nigel Grant Festschrift (2000): pp. 235-243. Print. 